\title{
Morphological features of the uterus during postnatal development in the West African Dwarf goat (Capra hircus)
}

\author{
Clifford Nwabugwu Abiaezute ${ }^{1,3}$, Innocent Chima Nwaogu ${ }^{1}$, Chidozie Nwabuisi Okoye ${ }^{2}$ \\ ${ }^{1}$ Department of Veterinary Anatomy. University of Nigeria, Nsukka, Nigeria. \\ ${ }^{2}$ Department of Veterinary Obstetrics and Reproductive Diseases. University of Nigeria, Nsukka, Nigeria.
}

\begin{abstract}
The knowledge of the age at which the West African Dwarf (WAD) goat attains puberty could be exploited to improve this breed of goat and intensify production. The objective of this study was to highlight the postnatal developmental morphology of the uterine tissues of the WAD goat from birth to 28 weeks of age. Fifty WAD goat kids were obtained and grouped into 10 groups of 5 goats per group from day old to week 28 . The uterine tissues of euthanized goats were dissected out and examined grossly. Thereafter fixed uterine tissues were prepared for light microscopy and stained with haematoxylin and eosin. Histological images of the uterine tissues were captured with a moticam camera. The length and weight of the uterine horns increased significantly $(\mathrm{P}<0.05)$ from birth to week 28 respectively. The uterine horn was shaped like a ram's horn. Internally, caruncles were prominent at birth and were regularly arranged in the uterine horn but irregularly arranged in the uterine body. Caruncles were absent in the cranial one third of the uterine horns. Histologically, the uterine horn and uterine body were similar. The endometrium was very cellular at birth without any form of glandular development, while the myometrium and the stratum vasculare were ill defined. Endometrial glands were first observed at week 1. The pseudostratified columnar epithelium of the mucosa at birth changed to simple columnar by week 12 . The endometrium and the myometrium were well developed by week 12 . In conclusion, the uterus of WAD goat at week 12 appeared similar to the uterus of an adult WAD goat indicating that this goat probably attains puberty earlier than the five - seven months previously reported.
\end{abstract}

Keywords: caruncles, endometrial glands, myometrium, postnatal development, West African Dwarf goat.

\section{Introduction}

The adult ruminant has a bicornuate type of uterus which is a Y shaped muscular, highly expandable tubular organ with a short body and two long tapering horns that is continuous with the uterine tubes cranially and the cervix caudally (Dyce et al., 2002; Budras and Habel, 2003). Internally, the uterus contains caruncles which are described as glands free while the intercaruncular areas contain large numbers of microscopic endometrial glands (Atkinson et al., 1984; Gray et al., 2001a). In synepitheliochorial type of placentation exhibited by ruminants, the caruncles are the site of implantation and fusion while the intercaruncular areas contain numerous glands that synthesize and secrete the histotroph (Amoroso, 1952; Bazer, 1975; Gray et al., 2001a; Igwebuike, 2009).

Mammalian uterine development is initiated in the fetus from the paramesonephric ducts. The inner mesoepithelial cells of the paramesonephric duct differentiates into the luminal and glandular epithelium, while the mesenchyme differentiates into the endometrial stroma and the myometrium of the uterus (Wiley et al., 1987; Kurita and Nakamura, 2008; Gonzalez and Behringer, 2009). However, mammalian uterine development is only completed during the postnatal period which establishes the three classic histological elements of the uterine wall including the endometrium, myometrium and perimetrium (Bartol et al., 1999; Gray et al., 2001a; Spencer et al., 2005; Cooke et al., 2013).

It is well known that reproduction is the primary target of economical importance in all animal production systems and early attainment of puberty is encouraged. The age of attainment of puberty in different goat breeds varies as some attain puberty between three to seven months (Michel and Rabie, 1991; Greyling, 2000; Bukar et al., 2006) while others attain puberty after one year (Simplicio et al., 1990; AlHosab and Basiouni, 1999). Goats are prolific breeders and the most abundant ruminant in Nigeria with an estimated population of 53.8 million, contributing about $35 \%$ of the total national meat supply and raw materials for agro-based industries (Maina, 2002; Oni, 2002; Abdel Aziz, 2010) thus contributing to the growth of the national economy. The West African Dwarf (WAD) goat, a miniature breed native to southern Nigeria has adapted to the humid tropical environment, is cheap to rear, tolerant to trypanosomosis and has high fertility and prolificacy rate (Udoh et al., 2010). Due to the absence of religious and cultural taboos of their products, the WAD goat meets the socioeconomic, cultural and recreational needs of the people (Devendra, 1992). It also serves as an excellent laboratory and pet animal (Taylor and Field, 2001). The WAD goat breeds throughout the year unlike temperate goats which have restricted breeding season and has been reported to attain puberty at five to seven months based on oestrous observations (Akusu et al., 1986; Chiboka et al., 1988). Numerous reproductive studies have been conducted on the WAD goat (Kirkpatrick and Akindele, 1974; Otchere and Nimo, 1975; Devendra and Burns, 1983; Akusu et al., 1986; Akusu, 1994; Udoh et al., 2010; 
Igwebuike and Ezeasor, 2013; Abiaezute and Nwaogu, 2015; Abiaezute et al., 2017) but none is on the developmental morphology of the uterine tissues. A large body of knowledge also exists on the prenatal and postnatal developmental morphology of the uterine tissues of other domestic animals (Desjardins and Hafs, 1969; Atkinson et al., 1984; Michel and Rabie, 1991; Bartol et al., 1993; Gray et al., 2001b; Bukar et al., 2006; Hayashi et al., 2008). However, these studies were on breeds of domestic animals not indigenous to the tropical climate. Moreover, most description of the goat reproductive anatomy is based on assumptions of similarities with the sheep (Smith, 1986; Adigwe and Fayemi, 2005). More also, knowledge of the age of attainment of puberty will aid to institute assisted reproductive techniques in WAD goats, whose improvement is necessary to intensify production. This will assist WAD goat producers to effectively supply a domestic and possibly external trade demand that could provide the farmers with improved source of living. Therefore the present study seeks to investigate the morphological changes that may occur in the uterine tissues from birth to week 28 in the West African Dwarf (WAD) goats.

\section{Materials and Methods}

All animal procedures were carried out with approval from the University of Nigeria Nsukka Senate Committee on Medical and Scientific Research Ethics. Fifty female WAD goats of known ages were used in this study. The female goats were sourced from local WAD goat breeders in Nsukka Local Government Area of Enugu state, Nigeria. The goats were purposively assigned to ten groups of five goats each including day old, week 1 , week 2 , week 4 , week 8 , week 12 , week 16 , week 20 , week 24 , and week 28 of age. Each goat was weighed and euthanized by intravenous injection of $70 \mathrm{mg} \mathrm{kg}-1$ sodium pentobarbitone (Kyron Laboratories Ltd, Johannesburg, South Africa). The uteri were dissected out and trimmed of extraneous tissues. The length and weight of each uterine horn and uterine body were determined with a meter rule and digital weighing balance (Model AUW 120 Series Shimadzu®, Kyoto, Japan). The uteri were incised open and the internal features were examined and noted.

\section{Histological preparation}

Segments of the uterine horns and uterine body from each group were cut and fixed by immersion in Bouin's fluid for $24 \mathrm{~h}$. The segments were dehydrated in increasing concentrations of ethanol, cleared in xylene and embedded in paraffin wax. Five $\mu \mathrm{m}$ thick sections were obtained using a rotary microtome (Model 1512; Leitz ${ }^{\circledR}$, Wetzlar, Germany) and were mounted on clean glass slides. The sections were stained with hematoxylin and eosin and studied under the Leica light microscope (Leica Galen II, Wetzlar, Germany). The thickness of the tunica muscularis of each segment of the uterine body for each group was measured using the ocular micrometer gauge calibrated with the stage micrometer gauge at $100 \mathrm{X}$ magnification. Images were then captured using Moticam Camera 1000 (Motic China group Ltd., Xiemen, China).

The means and standard errors (Mean $\pm \mathrm{SE}$ ) of the data obtained (length and weight of uterine horns, uterine bodies and their organ-body mass indices and the histomorphometry of the tunica muscularis of the uterine bodies) were calculated. The data were analysed by one way analysis of variance (ANOVA) and Duncan new multiple range test using SPSS (version 15.0; SPSS Inc., Chicago, USA). Significance was accepted at probability level of $\mathrm{P}<0.05$.

\section{Result}

\section{Gross anatomical features}

In all groups studied, the left and right uterine horns extended from the uterotubal junction with the uterine tubes and coursed caudally to meet the body of the uterus. Both horns were joined together at the caudal one third as they entered the body of the uterus by a ventral and dorsal transparent sheet, interconual ligaments. From its junction with the uterine tubes, the horn started as a very narrow tube that gradually enlarged in diameter as it coursed caudally in a spiral manner resembling a ram's horn. The body of the uterus extended from the points of entry of the paired uterine horns cranially to the firm constricted cervix caudally and represented a small portion of the entire uterus.

The length and weight of the left and right uterine horns showed statistically significant increases $(\mathrm{P}<0.05)$ as the goats aged (Table 1$)$. There were no statistically significant differences $(\mathrm{P}>0.05)$ in the length and weight of the left uterine horn from that of the right horn within groups studied. Likewise, length and weight of the uterine body increased significantly ( $P$ $<0.05$ ) with age (Table 1$)$. The percentage contributions of the weights of the left and right uterine horns and the uterine body to the body weights of the goat kids showed significant differences $(\mathrm{P}<0.05)$ with increase in age (Table 2).

Internally within the horn and body of the uterus were numerous prominent oval to quadrilateral shaped raised fleshy thickenings of the mucosa, caruncles (Fig. 1). These caruncles were regularly spaced out and longitudinally arranged in four rows in the middle and caudal thirds of the uterine horns (Fig. 2 ). The caruncles became irregularly arranged and less conspicuous to absent towards the tip or cranial one third of the horn. The caruncles within the body of the uterus were irregularly arranged and less numerous. Between the caruncles were the uterine mucosal folds. These arrangements were similar in all groups of female WAD goats studied. At birth, the caruncles were small and creamy in colour but became more prominent and pale to pinkish with increase in age of the goat (Fig. 1 and 2). 


\section{(b)}

Table 1. Table 1 mean length $(\mathrm{cm})$ and weight $(\mathrm{g})$ of uterine horns and body of WAD goat during postnatal growth.

\begin{tabular}{|c|c|c|c|c|c|c|c|c|c|c|}
\hline & Birth & Wk 1 & Wk 2 & Wk 4 & Wk 8 & Wk 12 & Wk 16 & Wk 20 & Wk 24 & Wk 28 \\
\hline \multirow[t]{2}{*}{ Number of goats } & 5 & 5 & 5 & 5 & 5 & 5 & 5 & 5 & 5 & 5 \\
\hline & & Length & & & & & & & & \\
\hline Left uterine horn & $2.70 \pm 0.43^{\mathrm{a}}$ & $3.03 \pm 0.33^{\mathrm{ab}}$ & $3.16 \pm 0.26^{\mathrm{ab}}$ & $3.72 \pm 0.46^{\mathrm{b}}$ & $5.30 \pm 0.93^{\mathrm{c}}$ & $5.50 \pm 0.66^{\mathrm{c}}$ & $5.94 \pm 0.57^{\mathrm{c}}$ & $7.34 \pm 1.18^{\mathrm{cd}}$ & $8.15 \pm 1.50^{\mathrm{d}}$ & $8.34 \pm 1.22^{\mathrm{d}}$ \\
\hline Right uterine horn & $2.94 \pm 0.29^{\mathrm{a}}$ & $3.05 \pm 0.32^{\mathrm{a}}$ & $3.18 \pm 0.25^{\mathrm{ab}}$ & $3.90 \pm 0.47^{b}$ & $5.40 \pm 0.95^{\mathrm{c}}$ & $5.71 \pm 0.78^{\mathrm{c}}$ & $6.09 \pm 0.53^{\mathrm{c}}$ & $7.27 \pm 1.00^{\mathrm{cd}}$ & $8.14 \pm 1.82^{\mathrm{cd}}$ & $8.52 \pm 1.23^{\mathrm{d}}$ \\
\hline \multirow[t]{2}{*}{ Uterine body } & $0.48 \pm 0.04^{\mathrm{a}}$ & $0.49 \pm 0.04^{\mathrm{a}}$ & $0.51 \pm 0.04^{\mathrm{a}}$ & $0.60 \pm 0.04^{\mathrm{ab}}$ & $0.73 \pm 0.08^{b}$ & $0.77 \pm 0.04^{\mathrm{b}}$ & $1.01 \pm 0.06^{\mathrm{c}}$ & $1.15 \pm 0.09^{\mathrm{cd}}$ & $1.24 \pm 0.08^{\mathrm{de}}$ & $1.41 \pm 0.08^{\mathrm{e}}$ \\
\hline & & Weight & & & & & & & & \\
\hline Left uterine horn & $0.14 \pm 0.03^{\mathrm{a}}$ & $0.16 \pm 0.02^{\mathrm{a}}$ & $0.21 \pm 0.02^{\mathrm{b}}$ & $0.49 \pm 0.06^{\mathrm{c}}$ & $0.96 \pm 0.26^{\mathrm{de}}$ & $0.71 \pm 0.08^{\mathrm{d}}$ & $0.80 \pm 0.10^{\mathrm{d}}$ & $0.84 \pm 0.09^{\mathrm{d}}$ & $1.14 \pm 0.10^{\mathrm{e}}$ & $1.34 \pm 0.17^{\mathrm{e}}$ \\
\hline Right uterine horn & $0.14 \pm 0.03^{\mathrm{a}}$ & $0.16 \pm 0.03^{\mathrm{ab}}$ & $0.21 \pm 0.03^{b}$ & $0.47 \pm 0.08^{c}$ & $0.95 \pm 0.24^{\mathrm{de}}$ & $0.70 \pm 0.08^{\mathrm{d}}$ & $0.80 \pm 0.10^{\mathrm{d}}$ & $0.85 \pm 0.10^{\mathrm{d}}$ & $1.11 \pm 0.13^{\mathrm{e}}$ & $1.31 \pm 0.18^{\mathrm{e}}$ \\
\hline Uterine body & $0.01 \pm 0.01^{\mathrm{a}}$ & $0.03 \pm 0.01^{\mathrm{a}}$ & $0.05 \pm 0.01^{\mathrm{ab}}$ & $0.08 \pm 0.01^{\mathrm{b}}$ & $0.22 \pm 0.02^{\mathrm{c}}$ & $0.25 \pm 0.02^{\mathrm{c}}$ & $0.31 \pm 0.02^{\mathrm{d}}$ & $0.44 \pm 0.02^{\mathrm{e}}$ & $0.70 \pm 0.03^{\mathrm{f}}$ & $1.01 \pm 0.03^{\mathrm{g}}$ \\
\hline
\end{tabular}

Figures with different superscripts $\left({ }^{\text {abcdef }}\right)$ in a row indicate significant difference $(\mathrm{P} \leq 0.05)$.

Table 2. Organ-body mass indices of WAD goat uterine horns and body during postnatal growth.

\begin{tabular}{|c|c|c|c|c|c|c|c|c|c|c|}
\hline & Birth & Wk 1 & Wk 2 & Wk 4 & Wk 8 & Wk 12 & Wk 16 & Wk 20 & Wk 24 & Wk 28 \\
\hline Number of goats & 5 & 5 & 5 & 5 & 5 & 5 & 5 & 5 & 5 & 5 \\
\hline Left uterine horn & $0.014 \pm 0.001^{\mathrm{a}}$ & $0.012 \pm 0.002^{\mathrm{a}}$ & $0.013 \pm 0.002^{\mathrm{a}}$ & $0.022 \pm 0.003^{\mathrm{b}}$ & $0.030 \pm 0.003^{\mathrm{c}}$ & $0.018 \pm 0.004^{\mathrm{a}}$ & $0.018 \pm 0.004^{\mathrm{a}}$ & $0.012 \pm 0.002^{\mathrm{a}}$ & $0.014 \pm 0.002^{\mathrm{a}}$ & $0.014 \pm 0.002^{\mathrm{a}}$ \\
\hline Right uterine horn & $0.015 \pm 0.003^{\mathrm{ab}}$ & $0.012 \pm 0.002^{\mathrm{a}}$ & $0.014 \pm 0.003^{\mathrm{ab}}$ & $0.020 \pm 0.003^{b}$ & $0.030 \pm 0.003^{\mathrm{c}}$ & $0.018 \pm 0.004^{\mathrm{ab}}$ & $0.016 \pm 0.002^{\mathrm{ab}}$ & $0.014 \pm 0.002^{\mathrm{a}}$ & $0.014 \pm 0.002^{\mathrm{a}}$ & $0.014 \pm 0.002^{\mathrm{a}}$ \\
\hline Uterine body & $0.001 \pm 0.0002^{\mathrm{a}}$ & $0.002 \pm 0.0002^{\mathrm{a}}$ & $0.003 \pm 0.0007^{b}$ & $0.004 \pm 0.0003^{b}$ & $0.008 \pm 0.002^{\mathrm{c}}$ & $0.007 \pm 0.001^{\mathrm{c}}$ & $0.006 \pm 0.001^{\mathrm{c}}$ & $0.006 \pm 0.001^{\mathrm{c}}$ & $0.009 \pm 0.002^{\mathrm{c}}$ & $0.010 \pm 0.002^{\mathrm{c}}$ \\
\hline
\end{tabular}

Figures with different superscripts $\left({ }^{\text {abcd }}\right)$ in a row indicate significant difference $(\mathrm{P} \leq 0.05)$. 

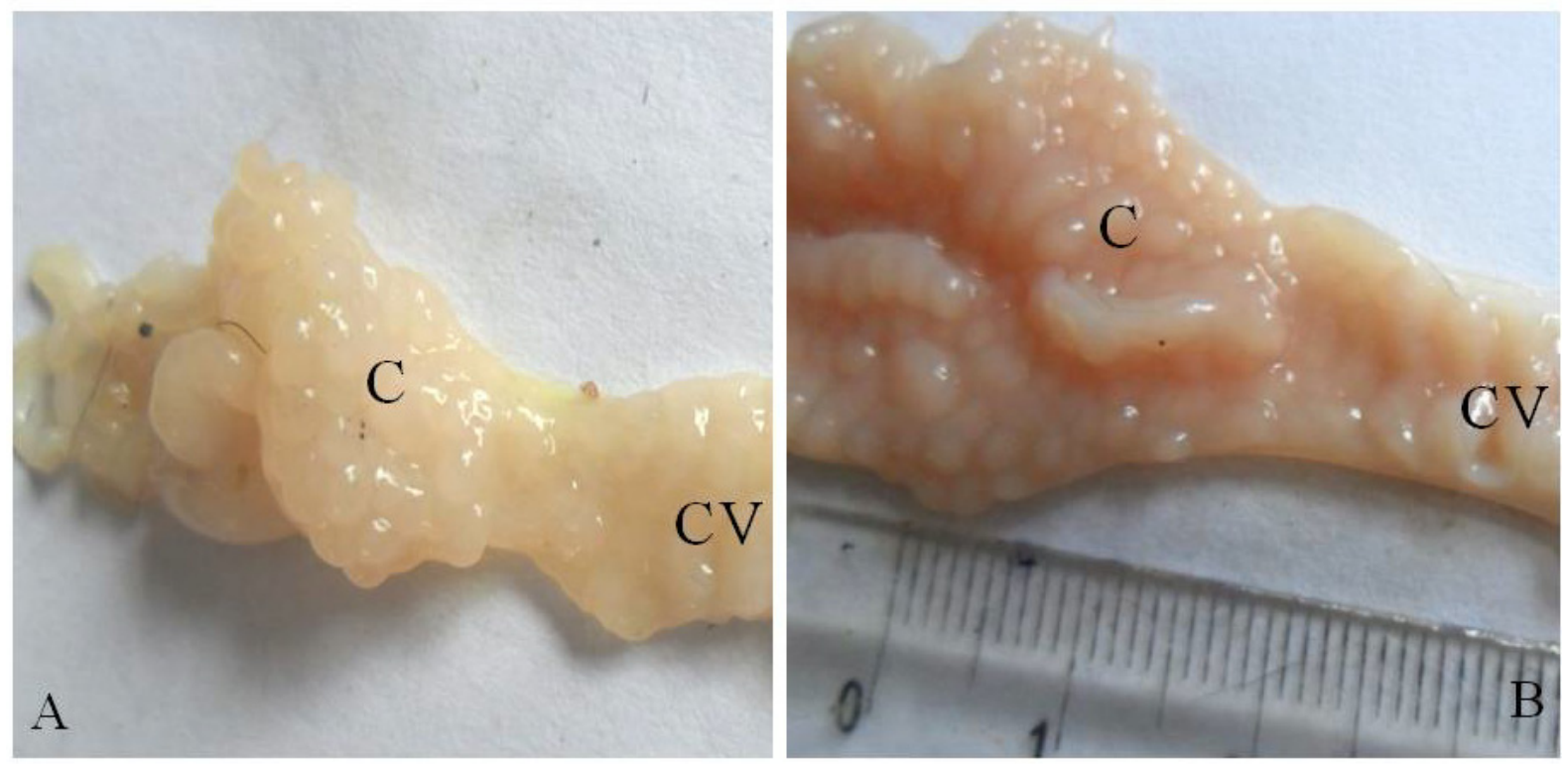

Figure 1. Gross appearance of the mucosa of the uterus of WAD goat at birth and week 12 showing the caruncles (C) and the cranial cervix (CV).

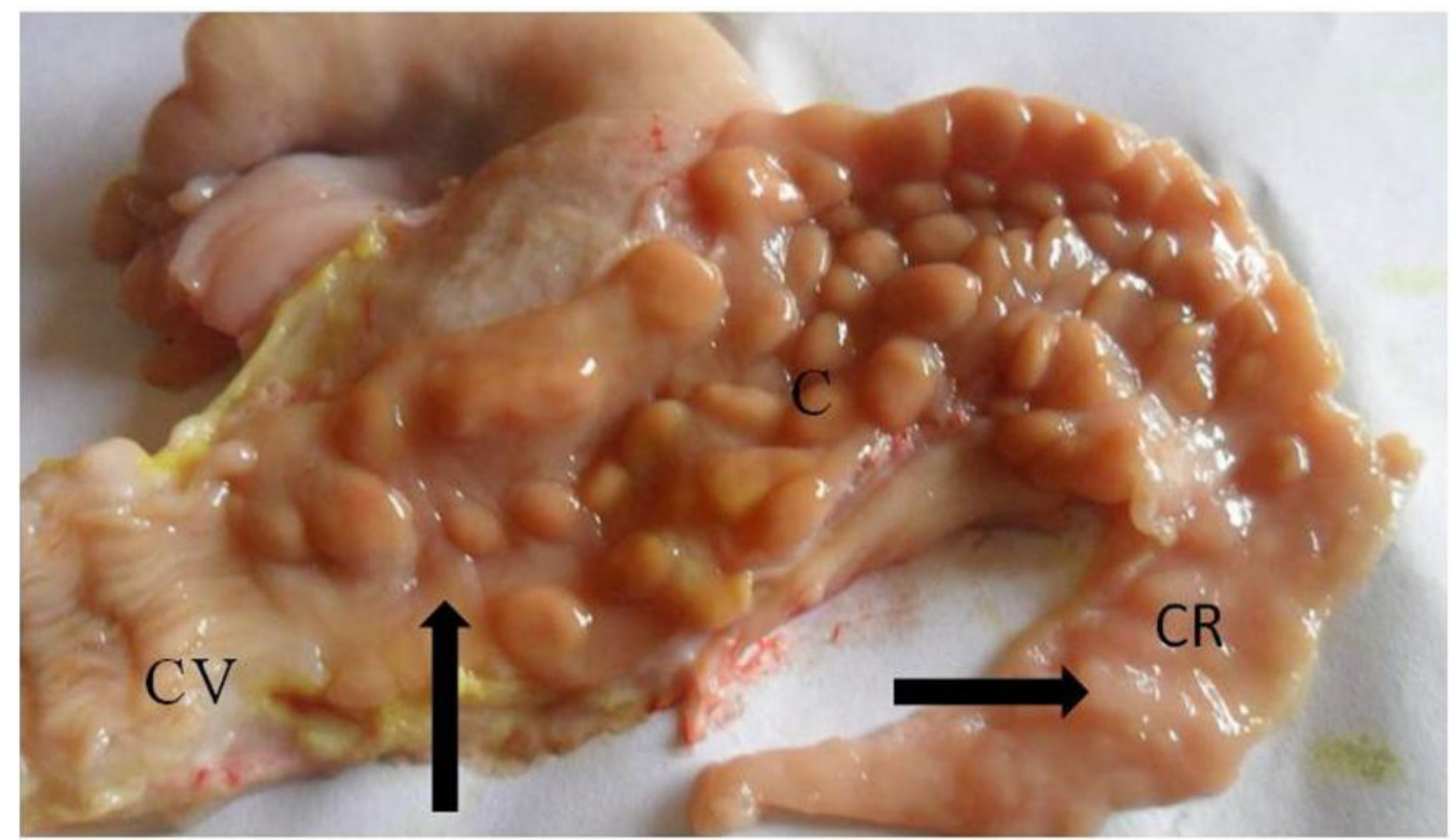

Figure 2. Gross photograph of the mucosa of the uterus of WAD goat at week 28 showing part of the cervix (CV), uterine caruncles $(\mathrm{C})$ and the uterine mucosal folds (arrows). Note the absence of caruncles in the cranial one third of the uterine horn (CR).

\section{Histology}

The uterine horn and uterine body within each age group had similar histological features in the goats studied. Within their lumen projected numerous caruncles above the mucosal surface. The caruncles were separated from each other by the intercaruncular areas which were thrown into folds separated by shallow grooves (mucosal folds). In the absence of lamina muscularis mucosae, the very cellular connective tissue of the lamina propria blended with the connective tissue of the submucosa and together, extended into and formed the core of the caruncles and mucosal folds. There were no noticeable glands in the endometrium at birth and the epithelium was pseudostratified columnar. However, endometrial glands were first observed at week 1 as buds and invaginations of the luminal epithelium into the underlying connective tissues (Fig. 3). A thin cellular layer of the stratum vasculare with small blood vessels was observed within the ill defined tunica muscularis or myometrium. The perimetrium, the outer loose connective tissue or the tunica serosa was lined by a simple squamous epithelium. 


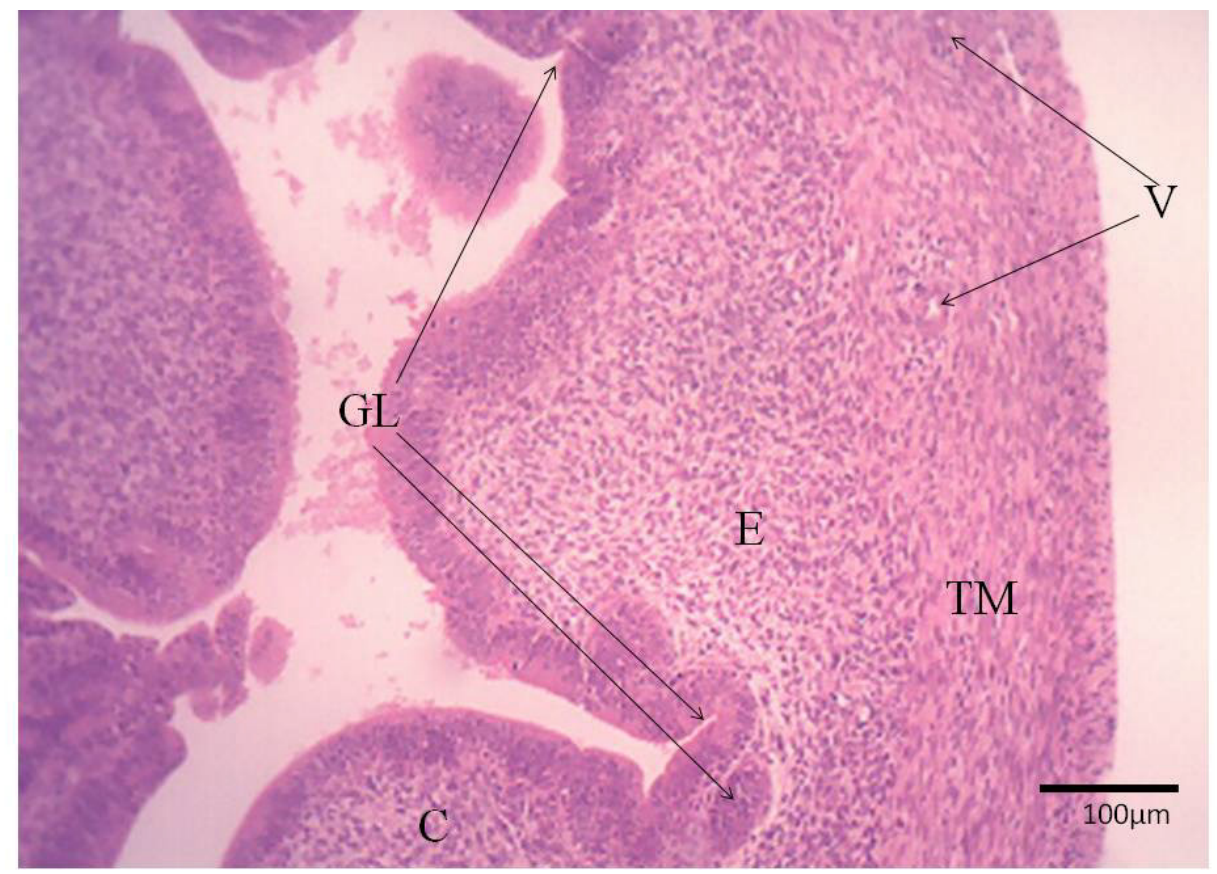

Fig. 3. Cross section of the uterus of WAD goat at week 1 showing the endometrial caruncle $(\mathrm{C})$, endometrium (E), blood vessel $(\mathrm{V})$ of the thin stratum vasculare within the tunica muscularis (TM) and the tunica serosa (TS). Note the early forms of endometrial glands (GL).

The uterus at week 2 was similar to the uterus at week 1. However, more endometrial glands were observed within the lamina propriaubmucosa of the intercaruncular area between adjacent caruncles (Fig. 4). The developing endometrial glands at this stage appeared as simple tubular glands that invaginated from the luminal epithelium into the lamina propria-submucosa. The thickness of the myometrium increased significantly $(P<0.05)$ with age (Table 3). Further development of the uterus as the goat aged involved extensive endometrial gland development which included branching and coiling within the lamina propria-submucosa. Also, the stratum vasculare and the myometrium increased in size as the goat aged and the blood vessels became larger and more numerous. At week 12, the uterus was at a very advanced stage of development with well defined caruncles, numerous endometrial glands all over the lamina propria-submucosa except within the caruncles (Fig. 5A). The myometrium was well developed with an inner circular and outer longitudinal smooth muscle layers. Also within the tunica muscularis, the stratum vasculare was well defined with numerous blood vessels. The uteri of the weeks 1628 old female WAD goats were very similar to the uterus of the week 12 old female WAD goats (Fig. 5B). The epithelial lining of the mucosa transited from pseudostratified columnar epithelium at birth (Fig. 6A) to a complete simple columnar epithelium at week 12 (Fig. 6B).

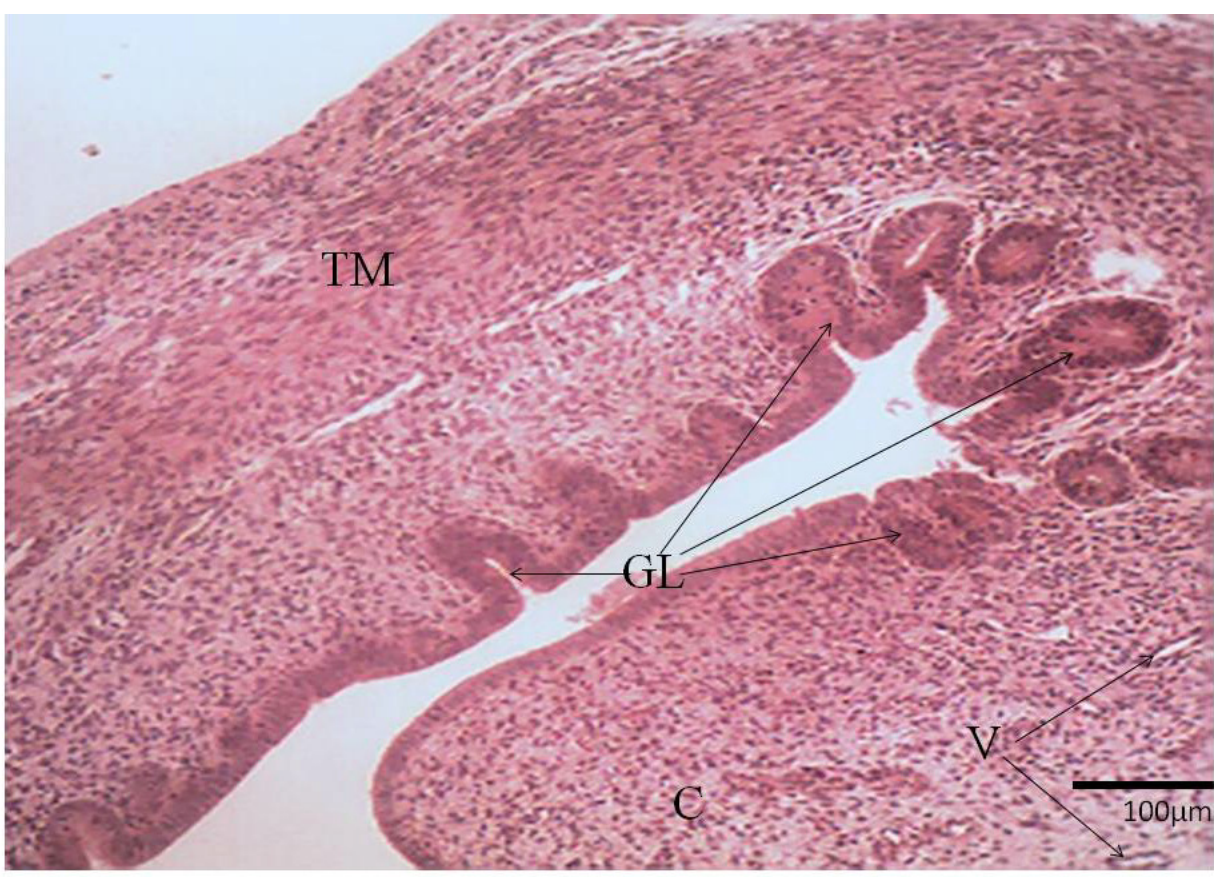

Fig. 4. Photomicrograph of the uterus of WAD goat at week 2 showing early forms of blood vessels (V) within the caruncle (C), tunica muscularis (TM) and tunica serosa (TS). Note the glands (GL) at the intercaruncular area. H \& E. 


\section{Qbo}

Table 3. Histomorphometry of the tunica muscularis of the uterine body of WAD goat during postnatal growth.

\begin{tabular}{|c|c|c|c|c|c|c|c|c|c|c|}
\hline & Birth & Wk 1 & Wk 2 & Wk 4 & Wk 8 & Wk 12 & Wk 16 & Wk 20 & Wk 24 & Wk 28 \\
\hline Number of goats & 5 & 5 & 5 & 5 & 5 & 5 & 5 & 5 & 5 & 5 \\
\hline Tunica muscularis & $10.90 \pm 0.94^{\mathrm{a}}$ & $11.50 \pm 1.1^{\mathrm{a}}$ & $19.10 \pm 2.76^{b}$ & $28.30 \pm 4.67^{\mathrm{c}}$ & $38.90 \pm 3.80^{\mathrm{d}}$ & $48.30 \pm 5.05^{\mathrm{e}}$ & $56.50 \pm 6.38^{\mathrm{ef}}$ & $65.20 \pm 4.41^{\mathrm{f}}$ & $72.30 \pm 4.40^{\mathrm{fg}}$ & $79.10 \pm 4.23^{\mathrm{g}}$ \\
\hline
\end{tabular}

Figures with different superscripts $\left(^{\mathrm{abcd}}\right)$ in a row indicate significant difference $(\mathrm{P} \leq 0.05)$.
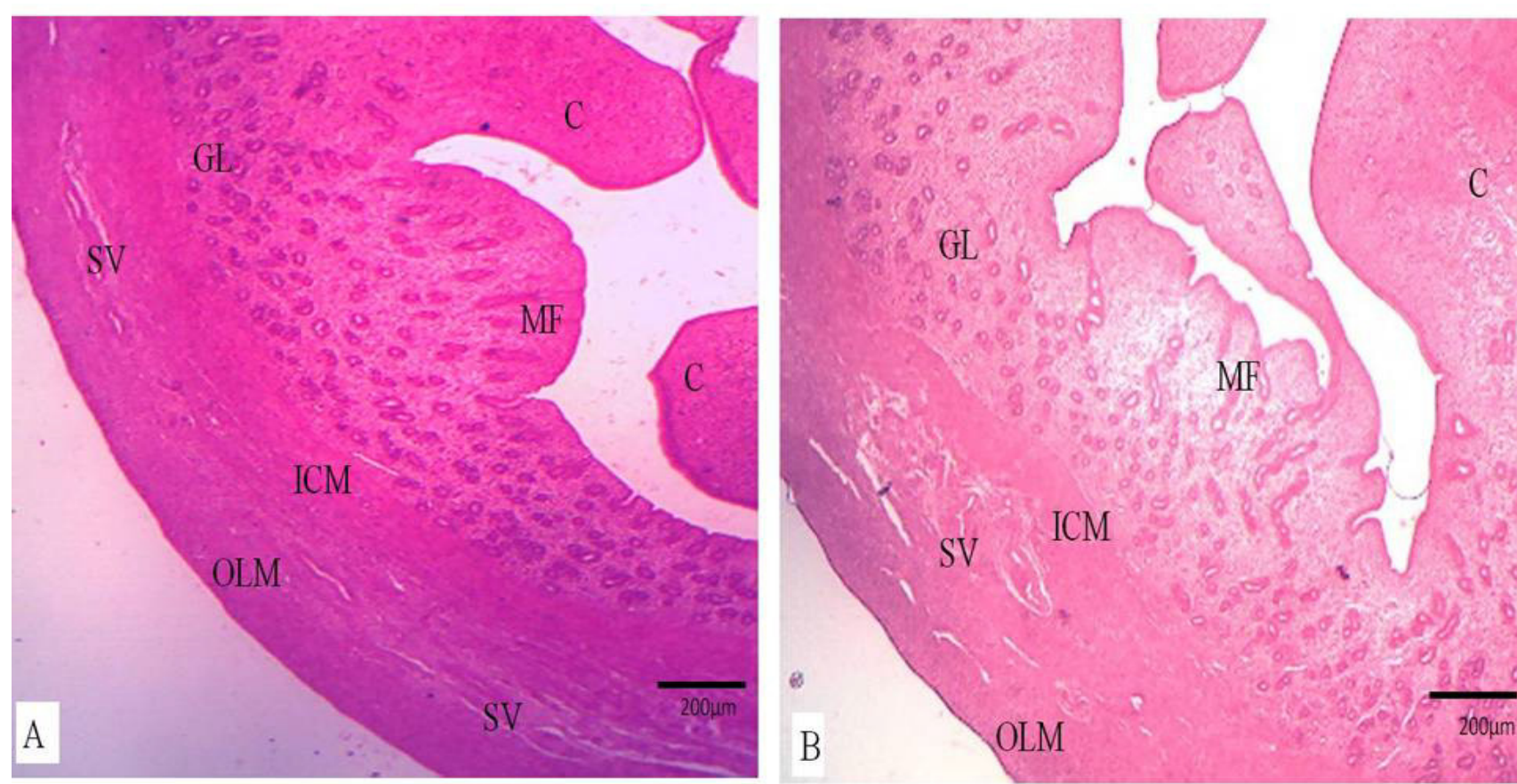

Figure 5. Cross section of the uterus of WAD goat at week 12 (A) and week 24 (B) showing well developed stratum vasculare (SV) between the outer longitudinal (OLM) and inner circular (ICM) smooth muscle layers. Note the caruncle (C), mucosal folds (MF) and the numerous glands (GL) within the endometrium. $\mathrm{H} \& \mathrm{E}$ 

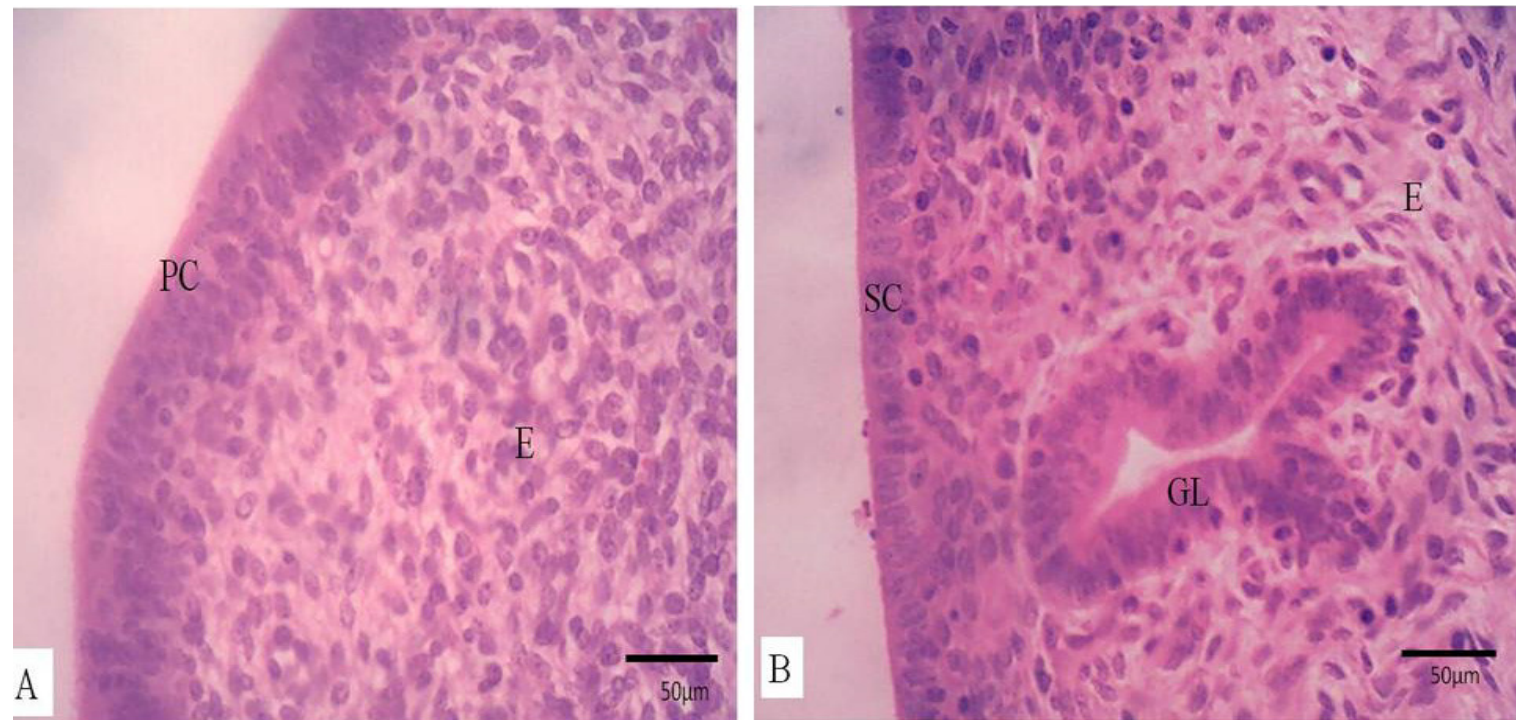

Figure 6. Photomicrograph of the epithelium of the uterus of WAD goat at birth (A) and week 12 showing the pseudostratified columnar epithelium (PC) and the simple columnar epithelium (SC). Note the endometrial gland $(\mathrm{GL})$ in the cellular endometrium (E) at week $12 . \mathrm{H} \& \mathrm{E}$.

\section{Discussion}

This study provides information on the gross and microscopic features of the uterus of WAD goat from birth to week 28. Grossly, the uteri of the WAD goat in all age groups studied were similar. However, there was a statistically significant increase $(\mathrm{P}<0.05)$ in length and weight as the animal aged. This pattern of uterine growth was similar to that observed in small ruminants (Kennedy et al., 1974; Bukar et al., 2006; Hayashi et al., 2008). These could be due to increased development of the uterine tissues occasioned by the increase in the numbers and activities of the endometrial glands and the proliferation of the cellular components of the uterine wall.

The numerous prominent raised caruncles in the uteri of the WAD goat at birth which were reportedly not prominent in Sahel goats at birth (Sivachelvan et al., 2002; Bukar et al., 2006) suggest prenatal caruncular morphogenesis. Similar observations have been reported in ewe lambs at birth (Wiley et al., 1987; Bartol et al., 1999; Hayashi et al., 2008). This study demonstrated the absence of caruncles in the cranial one third of the uterine horns in WAD goats of all ages. This is at variance with report of caruncles observed in all parts of the uterine horn including the tips of the horns in ewe and cow (Stevens et al., 1981; Habel, 1989; Dyce et al., 2002) and goats (Lyngest, 1968). This arrangement in WAD goat also reported in adult goats in Egypt (Abd-Elnaeim, 2008) could be an adaptation to prevent implantation of foetuses in the small, narrow and spiral shaped cranial portion of the uterine horn.

The quadrilateral shaped caruncles in this study appeared as raised fleshy thickening of the mucosa similar to that reported by Abd-Elnaeim (2008) in adult goats in Egypt, thus suggesting non-stalked caruncles that are closer to the mucosal surface of the uterus This differed from the round to oval gently sloping hillocklike caruncles in sheep (Stevens et al., 1981) and mushroom or dome shaped caruncles with stalks in bovine (Pfarrer et al., 2001; Dyce et al., 2002; Budras and Habel, 2003). These non stalked quadrilateral caruncles in WAD goats probably favoured firmer attachment of the placenta to the uterine wall.

Histologically, the uterus of WAD goat showed a marked postnatal uterine morphogenesis similar to the uterine development of ewe (Kennedy et al., 1974; Bartol et al., 1988a; Hayashi et al., 2008), Syrian goat (Michel and Rabie, 1991) and Sahelian goat (Bukar et al., 2006) from birth to puberty. The postnatal events observed included the emergence and development of endometrial glands, development of endometrial stroma and the growth of the myometrium. The timing of these developmental events of the uterus is specie specific and reflects differences in uterine maturity at birth (Gray et al., 2001a). It may also be associated with the "programming" of uterine tissues for productivity in adult life (Kobayashi and Behringer, 2003; Bartol et al., 2008).

The developmental pattern of endometrial gland in this study was similar to the developmental pattern of endometrial glands in ewe (Kennedy et al., 1974; Wiley et al., 1987; Bartol et al., 1988b; Gray et al., 2001b; Hayashi et al., 2008) where endometrial gland development was initiated between day 0 and day 7. However, this pattern differed from that reported in Sahel goat kid where glandular development was first noticed from the second week (Bukar et al., 2006). In this study, the advanced development of uterine glands in the endometrium at week 12 suggests a uterus that appeared similar to that described for an adult small ruminant (Wiley et al., 1987; Shalini and Sharma, 2004; Samuelson, 2007; Abd-Elnaeim, 2008; Katare et al., 2015). The increased development with age of blood vessels within the caruncles and endometrial glands within the intercaruncular areas suggest the evolutionary adaptation of the WAD goat to its synepitheliochorial type of plancentation.

The growth and development of the 
myometrium and the stratum vasculare from birth to week 28 in this study suggests immaturity of these tissues at birth thus requiring further postnatal growth and development for productivity at puberty. The values of the myometrium in this study are lower than the values reported in prepubertal Indian goats (Singh and Prakash, 1990) and Gaddi goats (Shalini and Sharma, 2004). This variation may be due to the age, larger size and weight at attainment of puberty in these female goats. However, the morphology of the myometrium and the stratum vasculare at week 12 in this study were similar to that described for adult small ruminants (Wiley et al., 1987; Singh and Prakash, 1990; Banks, 1993; Shalini and Sharma, 2004; Samuelson, 2007; Katare et al., 2015). Further postnatal development of the myometrium may be related to their functions (Wimsat, 1950; Stewart et al., 2000; Gray et al., 2001b).

The patterns of development observed in this study agrees with reports that establishment of tissuespecific histoarchitecture of the uterus is only completed postnatally (Gray et al., 2001a; Spencer et al., 2005, 2012). Thus, it may be inferred that the uterus of WAD goat at week 12 of age may be similar to that of an adult WAD goat. This observation may indicate early attainment of puberty in WAD goats. Although Akusu et al. (1986) and Chiboka et al. (1988) reported first oestrus in WAD goats to occur between 5-7 months of age, more recent authors have shown that the goat may attain puberty as early as 3-4 months of age (Jainudeen et al., 2000; Khanum et al., 2000; Bukar et al., 2006; Abiaezute et al., 2017).

The present study has demonstrated the absence of caruncles in the cranial one third of the uterine horn. The study showed postnatal developments that established the three classic histological elements of the uterine wall (endometrium, myometrium and perimetrium) and the process of adenogenesis. More also, the WAD goat probably attains puberty at three to four months which is earlier than previously reported and this could be used to improve productivity in this breed.

\section{Conflict of interest}

The authors declare that there are no conflicts of interest regarding this study.

\section{References}

Abdel Aziz M. 2010. Present stature of the world goat populations and their productivity. Lohman Inf, 45:42-52. Abd-EInaeim MMM. 2008. Scanning electron microscopic study on the cyclic goat uterus with special reference to the microvascular architecture of the uterine caruncles. J Agric Vet Sci Qassim Univ, 1:21-32 Abiaezute CN, Nwaogu IC. 2015. Postnatal development of the vagina in West African Dwarf goat (Capra hircus). J Cell Anim Biol, 9:31-37.

Abiaezute CN; Nwaogu IC, Igwebuike UM. 2017. Evaluation of the morphological features of the uterine tubes during postnatal development in West African Dwarf goats (Capra hircus). Vet Res For, 8:1-6

Adigwe PI, Fayemi O. 2005. A Biometric study of the reproductive tract of the Red Sokoto (Maradi) goats of Nigeria. Pak Vet J, 25:149-150.

Akusu MO, Osuagwuh AIA, Akpokodje JU, Egbunike GN. 1986. Ovarian activities of the West African Dwarf goat (Capra hircus) during oestrus. $J$ Reprod Fertil, 78:459-462.

Akusu MO. 1994. The effect of plane of nutrition on vital reproduction statistics of west african dwarf goats. animal reproduction. In: Proceedings of a Regional Seminar. International Foundation for Science (IFS), Niamey, Niger. Niamey: IFS/University of Niamey. pp. 27-34.

Al-Hozab A, Basiouni G. 1999. Onset of puberty in Hebsi and Zomri goats as monitored by plasma progesterone concentrations. J Appl Anim Res, 15:6974.

Amoroso ES. 1952. Placentation. In: Parkes AS (Ed.). Marshall's Physiology of Reproduction. 3rd ed. London, UK: Longmans Green. pp. 127-316.

Atkinson BA, King GJ, Amoroso EC. 1984. Development of the caruncular and intercaruncular regions in the bovine endometrium. Biol Reprod, 30:763-764.

Banks WJ. 1993. Applied Veterinary Histology. 3rd ed. St. Louis, MO: Mosby. pp. 446-468.

Bartol FF, Wiley AA, Coleman DA, Wolfe DF, Riddell MG. 1988a. Ovine uterine morphogenesis: effects of age and progestin administration and withdrawal on neonatal endometrial development and DNA synthesis. $J$ Anim Sci, 66:3000-3009.

Bartol FF, Wiley AA, Goodlett DR. 1988b. Ovine uterine morphogenesis: histochemical aspects of endometrial development in the foetus and neonate. $J$ Anim Sci, 66:1303-1313.

Bartol FF, Wiley AA, Spencer TE, Vallet JL, Christenson RK. 1993. Early uterine development in pigs. J Reprod Fertil, 48:99-116.

Bartol FF, Wiley AA, Floyd JG, Ott TL, Bazer FW, Gray CA, Spencer TE. 1999. Uterine differentiation as a foundation for subsequent fertility. $J$ Reprod Fertil, 54:287-302.

Bartol FF, Wiley AA, Bagnell CA. 2008. Epigenetic programming of porcine endometrial function and the lactocrine hypothesis. Reprod Domest Anim, 43:273279.

Bazer FW. 1975. Uterine protein secretions: relationship to development of the conceptus. J Anim Sci, 41:1376-1382.

Budras K, Habel RE. 2003. Bovine Anatomy: an illustrated text. Hannover, Germany: Schlutersche. pp. 86-88.

Bukar MM, Amin JD, Sivachelvan MN, Ribadu AY. 2006. Postnatal histological development of the ovaries and uterus and the attainment of puberty in female kid goats. Small Rumin Res, 65:200-208.

Chiboka O, Somade B, Montsama G. 1988. Reproduction of West African Dwarf Goats: a summary of research work at Ile-Ife, Nigeria. In: Smith OB, Bosman HG (Ed.) Goat Production in Humid Tropics. Wageningen: Pudoc. 1988. pp. 125-136.

Cooke SC, Spencer TS, Bartol FF, Hayashi K. 2013. Uterine glands: development, function and experimental 
model systems. Mol Hum Reprod, 19:547-558.

Desjardins C, Hafs HD. 1969. Maturation of bovine female genitalia from birth through puberty. J Anim Sci, 28:502-507.

Devendra G, Burns M. 1983. Goat Production in the Tropics. 2nd ed. Farnham Royal, Slough, UK: Commonwealth Agricultural Bureaux. pp. 74-89.

Devendra C. 1992. Goats and rural prosperity. In: PreConference Proceedings. Vth. International Conference on Goats, New Delhi, India. New Delhi: IASR. pp. 6-25.

Dyce KM, Sack WO, Wensing CJG. 2002. Veterinary Anatomy. 3rd ed. Philadelphia, PA: Saunders. pp. $637-$ 639.

Gonzalez G, Behringer RR. 2009. Dicer is required for female reproductive tract development and fertility in the mouse. Mol Reprod Dev, 76:678-688.

Gray CA, Bazer FW, Spencer TE. 2001a. Effects of neonatal progestin exposure on female reproductive tract structure and function in the adult ewe. Biol Reprod, 64:797-804.

Gray CA, Johnson GA, Bartol FF, Tarleton BJ, Wiley AA, Bazer FW, Spencer TE. 2001b. Developmental biology of uterine glands. Biol Reprod, 65:1311-1323.

Greyling JPC. 2000. Reproduction traits in the Boer goat doe. Small Rumin Res, 36:171-177.

Habel RE. 1989. Guide to Dissection of Domestic Ruminants. New York, NY: Published by Robert E. Habel. 4th ed. pp. 95-105

Hayashi K, O'Connell AR, Juengel JL, McNatty KP, Davis GH, Bazer FW, Spencer TE. 2008. Postnatal uterine development in inverdale ewe lamb. Reproduction, 135:357-365.

Igwebuike UM. 2009. A review of uterine structural modifications that influence conceptus implantation and development in sheep and goats. Anim Reprod Sci, 112:1-7.

Igwebuike UM, Ezeasor DN. 2013. The morphology of placentomes and formation of chorionic villous trees in West African Dwarf goats (Capra hircus). Vet Arh, 83:312-321.

Jainudeen MR, Wahid H, Hafez ESE. 2000. Sheep and goats. In: Hafez ESE, Hafez B (Ed.). Reproduction in Farm Animals. 7th ed. Philadelphia, PA: Lippincott Williams and Wilkins. pp. 170-181.

Katare B, Singh G, Kumar P, Gahlot PK. 2015 Histomorphological studies on uterus of goat (Capra hircus) during follicular and luteal phase. Indian $J$ Vet Anat, 27:47-48.

Kennedy JP, Worthington CA, Cole ER. 1974. The postnatal development of the ovary and uterus of the Merino lamb. J Reprod Fertil, 36:275-282

Khanum SA, Hussain M, Ali M, Kausar R, Cheema AM. 2000. Age at puberty in female dwarf goat kids and eustrous cycle length on the basis of hormones. Pak Vet J, 20:71-76.

Kirkpatrick RL, Akindele Z. 1974. Reproduction in West African Dwarf goats. J Anim Sci, 39(1):163.

Kobayashi A, Behringer RR. 2003. Developmental genetics of the female reproductive tract in mammals. Nat Rev Genet, 4:969-980.

Kurita T, Nakamura H. 2008. Embryology of the uterus. In: Aplin JD, Fazleabas AT, Giudice LC (Ed.). Endometrium. London, UK: Informa Ltd. pp. 1-8.

Lyngest O. 1968. Studies on reproduction in the goat. Acta Vet Scand, 9:208-221.

Maina JA. 2002. Legal framework for the advancement and protection of the Veterinary profession in Nigeria. In: Proceedings at the 39th Nigerian Veterinary Medical Association Conference, Sokoto, Nigeria. Sokoto: NVMA. pp. 10-13.

Michel G, Rabie FO. 1991. Histological study of postnatal development of the uterus of dwarf goat Archiv Exp Vet, 45:15-20.

Oni OO. 2002. Breeds and genetic improvement of small ruminants (sheep and goats). In: Lakpini CAM, Adamu AM, Ehoche OW, Gefu JO (Ed.). Manual for Small Ruminant Production in Nigeria. Zaria National

Animal Production Research Institute. 97 pp.

Otchere EO, Nimo MC. 1975. Observations of reproductive behaviour in the West African Dwarf goat. Ghana J Agric Sci, 8:187-190

Pfarrer C, Ebert B, Miglino MA, Klisch K, Leiser R. 2001. The three-dimensional feto-maternal vascular interrelationship during early bovine placental development: a scanning electron microscopical study. $J$ Anat, 198:691-702.

Samuelson AD. 2007. Textbook of Veterinary Histology. St. Louis, MO: Saunders. pp. 443-486

Shalini S, Sharma DN. 2004. Micromorphology and histochemistry of uterus of Gaddi goats during reproduction and senility. Indian J Anim Res, 38:117120.

Simplicio AA, Pereira-de-Figueiredo EA, Riera GS, Foote WC. 1990. Puberty in four genotypes of female goats in Northeast Brazil. Pesq Agropec Bras, 25:455459

Singh GK, Prakash P. 1990. Effect of age on the morphological changes in the uterus of goat. Indian $J$ Anim Sci, 60:838-839

Sivachelvan MN, Amin JD, Turaki UA. 2002. Some developmental features of female fetal reproductive organs of sahel goats. Sahel J Vet Sci, 1:11-16.

Smith MC. 1986. Caprine reproduction. In: Marrow DA (Ed.). Current Therapy in Theriogenology. Philadelphia, PA: Saunders. pp. 577-579.

Spencer TE, Hayashi K, Hu J, Carpenter KD. 2005. Comparative developmental biology of the mammalian uterus. Curr Top Dev Biol, 68:85-122.

Spencer TE, Dunlap KA, Filant J. 2012. Comparative developmental biology of the uterus: insights into mechanisms and developmental disruption. Mol Cell Endocrinol, 354:34-53.

Stevens DH, Burton GJ, Samuel AC. 1981. Histology and electron microscopy of sheep placental membranes. Placenta, 2:11-34.

Stewart MD, Johnson GA, Gray CA, Burghardt RC, Schuler LA, Joyce MM, Bazer FW, Spencer, TE. 2000. Prolactin receptor and uterine milk protein expression in the ovine endometrium during the estrous cycle and pregnancy. Biol Reprod, 62:1779-1789

Taylor RE, Field TG. 2001. Goat breeding, feeding and management. In: Taylor RE, Field TG. Scientific Farm Animal Production. 7th ed. Upper Saddle River, 
NJ: Prentice-Hall. pp. 644-670.

Udoh EP, Egbunike GN, Sokunbi OA. 2010. Morphometric and biochemical characteristics of reproductive tract of post-pubertal West African Dwarf goats: a preliminary investigation. Nig J Agric Food
Environ, 6:6-12.

Wiley AA, Bartol FF, Barron DH. 1987. Histogenesis of the ovine uterus. J Anim Sci, 64:1262- 1269.

Wimsatt WA. (1950. New histological observations on the placenta of the sheep. Am J Anat, 87:391-436. 